\title{
Closing the gender pay gap in Canadian medicine
}

\author{
Michelle Cohen MD, Tara Kiran MD MSc
}

— Cite as: CMAJ 2020 August 31;192:E1011-7. doi: 10.1503/cmaj.200375

CMAJ Podcasts: author interview at https://www.cmaj.ca/lookup/doi/10.1503/cmaj.200375/tab-related-content

$\mathbf{T}$ he gender pay gap, defined as the difference between what men and women earn for roughly equivalent work, has remained a core challenge in employment equity despite decades of activist effort and the substantial movement of women into the workplace. The Canadian government is taking steps to address the issue broadly, ${ }^{1}$ but there has been little action thus far from health care leadership to address pay equity within the medical profession. In this article, we summarize evidence on the gender pay gap in medicine in Canada and abroad, and discuss common myths, likely root causes and possible solutions. We start with the premise that equal pay for equal work is a matter of fairness ${ }^{2}$ and is necessary for the profession to move from aspirations of gender inclusion to equity and justice for women. ${ }^{3}$ Gender is not binary; however, we focus on differences in pay between groups defined in the data as men and women. Currently, there is little research on the experiences of nonbinary physicians. ${ }^{4}$ In the broader Canadian workforce, the pay gap is larger for women who are Indigenous, racialized or newcomers, or are living with a disability. ${ }^{.}$However, there are few comparable data in medicine, ${ }^{6}$ and discussing how the intersection of different identities may affect pay disparity is beyond the scope of this article.

\section{Is the gender pay gap real?}

Numerous studies, mostly from the United States and the United Kingdom, have shown a clear gender pay gap among physicians. ${ }^{7-13}$ This effect is seen in clinical, ${ }^{14}$ research $^{15}$ and academic $^{16,17}$ environments. Inequities start at the early stages of a medical career, ${ }^{18,19}$ deepen with time, ${ }^{20}$ continue into retirement ${ }^{21}$ and affect lifetime wealth, ${ }^{22}$ with estimates as high as $\$ 2.5$ million over a 30-year career..$^{23}$ The pay gap in medicine persists after adjustment for factors like physician age, specialty, number of hours worked and practice characteristics. ${ }^{24,25}$

The limited data available in Canada suggest a similar situation. The proportion of women among Canadian physicians has grown rapidly, from $11 \%$ in 1978 to $43 \%$ in $2018 .{ }^{26}$ Yet data from Ontario show that women account for only $8 \%$ of the province's highest-billing physicians. ${ }^{27}$ Our own analysis of Canadian data, along with analysis done by others, suggest that some pay differences are driven by specialty but that there are also gender pay differences within specialties.

\section{KEY POINTS}

- Women in Canadian medicine consistently earn less than men.

- The pay gap between women and men exists within every medical specialty and also between specialties, with physicians in male-dominated specialties receiving higher payments.

- The gender pay gap in medicine is not explained by women working fewer hours or less efficiently but, rather, relates to systemic bias in medical school, hiring, promotion, clinical care arrangements, the fee schedule itself and societal structures more broadly.

- Actions for closing the gap include antioppression training, challenging the hidden curriculum in medical education, fair and transparent hiring and referral processes, changing the relative value of fee codes and transparent reporting of physician payments stratified by gender.

We used publicly available data to assess the relation between the proportion of women in a specialty and 1) the average gross payments by specialty across Canada and 2) the estimated net income by specialty (payments minus self-reported overhead) (see Appendix 1, available at www.cmaj.ca/lookup/ doi/10.1503/cmaj.200375/tab-related-content, for methods). Women made up less than $35 \%$ of physicians among 10 specialties with the highest gross and net incomes (Figure 1). In contrast, women accounted for $47 \%, 48 \%$ and $62 \%$ of physicians in the 3 specialties with the lowest estimated net income: family medicine, psychiatry and pediatrics. Other investigators have noted a trend in the feminization of specialties such as family medicine, ${ }^{28}$ and some have expressed concern that this represents a new "pink collar" tier of medicine that is relatively underpaid. ${ }^{29-31}$

Recent Ontario analyses highlight the gender pay gap within specialties. An analysis of data from the Ontario Medical Association showed that, on average, male family physicians earn $30 \%$ more and male specialists earn $40 \%$ more than their female counterparts. ${ }^{32}$ Moreover, men earn more than women within every specialty (Figure 2). A more sophisticated cross-sectional analysis of billing data showed that female surgeons were paid less than male surgeons in Ontario even after adjustment for age, years in practice, patient factors and surgical specialty. ${ }^{33}$ 
A

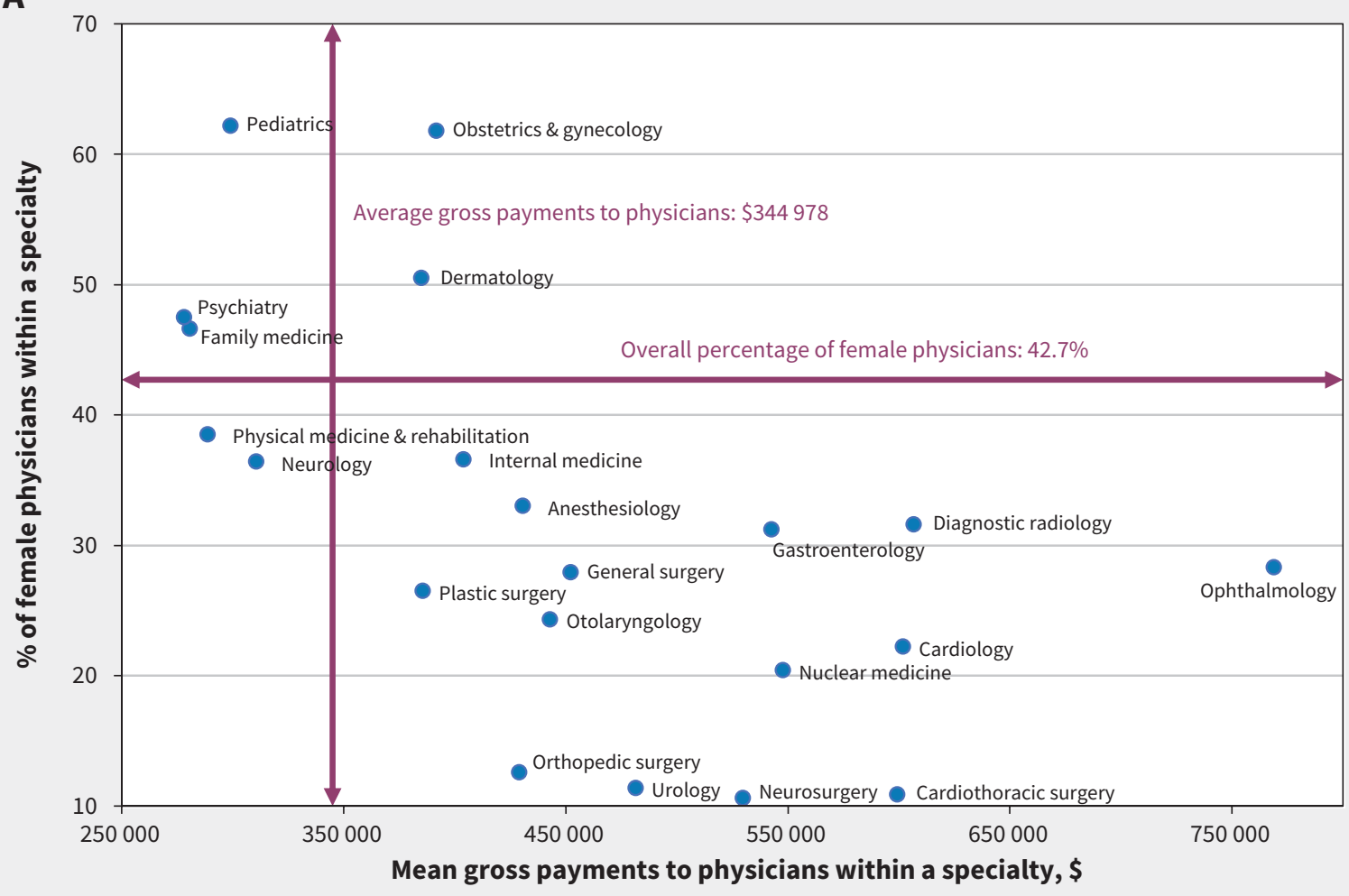

B

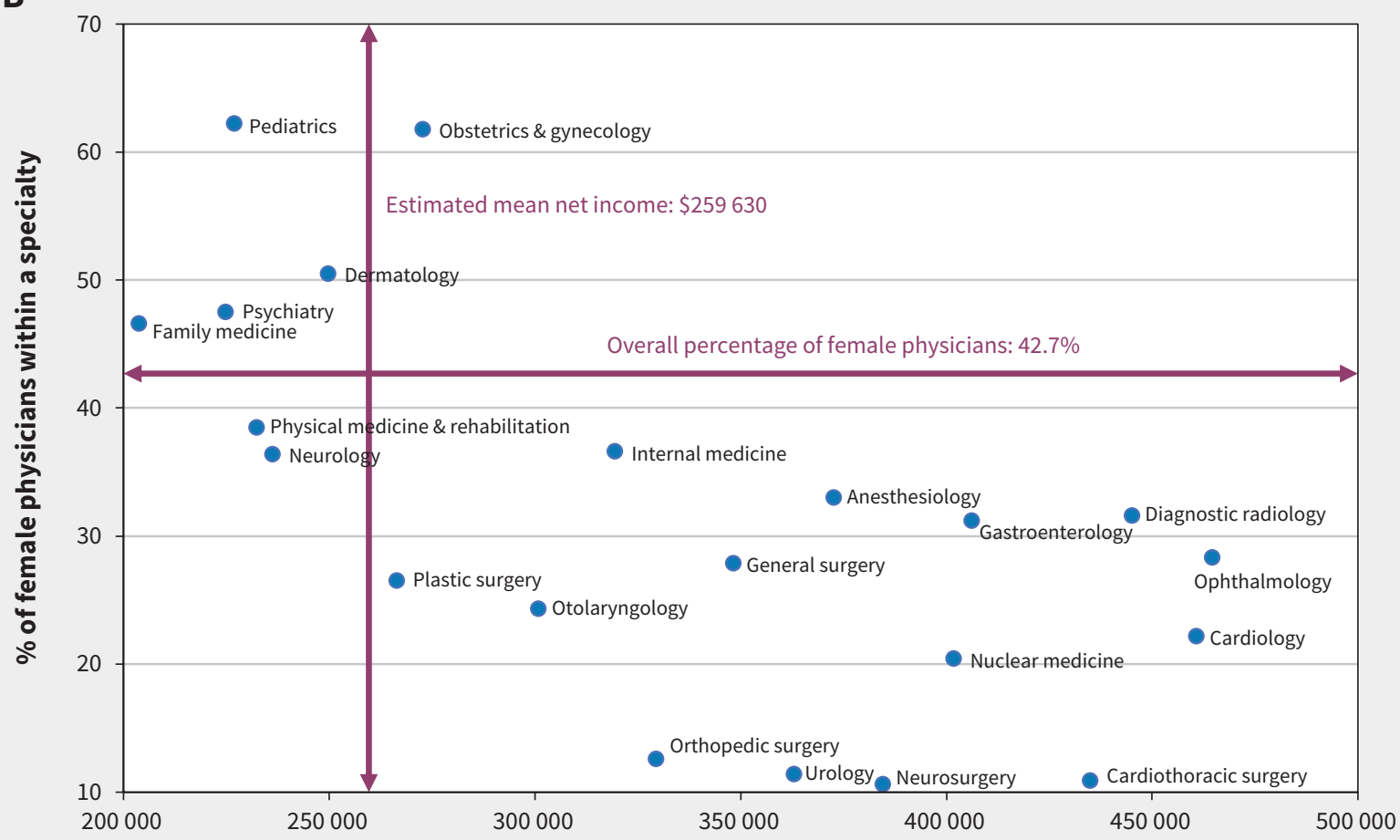

Estimated mean net income within a specialty, \$

Figure 1: (A) Scatterplot of the proportion of women in a specialty and the average gross payments per physician by specialty. (B) Scatterplot of the proportion of women in a specialty and the estimated average net income by specialty. Psychiatry includes geriatric psychiatry, child psychiatry and general psychiatry. Cardiac, cardiothoracic and thoracic surgery were combined into a single category. Pediatrics, internal medicine, and obstetrics and gynecology represent their general, but not subspecialty, categories. 


\section{Do women just work less (or less efficiently) than men?}

Most physician remuneration in Canada is based on a fee-forservice model, so it seems natural to presume that lower income is a result of women working less. However, the differences in work hours are not enough to fully explain the income gap. The Canadian Medical Association 2019 National Physician Survey (which included part-time and semiretired physicians) showed that, compared with men, women worked $4.7 \%$ fewer hours per week and $8.6 \%$ fewer hours on-call - small differences compared to the disparity in income. ${ }^{34} \mathrm{~A}$ study of primary care physicians in British Columbia in 2017 showed that women made $36 \%$ less than their male colleagues despite a patient care workload that differed by only 3.2 hours per week. ${ }^{35}$

Surveys of UK and US physicians showed that women were more likely to work part-time, but primarily if they had young children. ${ }^{36,37}$ Moreover, existing data suggest that having children results in a temporary decrease in work hours and that, over the course of their careers, women as a group do not work substantially less than men. A Canadian cohort analysis of general and family practitioners in 2008 showed a U-shaped curve in hours of direct patient care over the length of a woman's career, declining until roughly age 38 and then increasing to previous levels, a pattern consistent with child-bearing and early-stage child-rearing. ${ }^{38} \mathrm{~A}$ study using American Medical

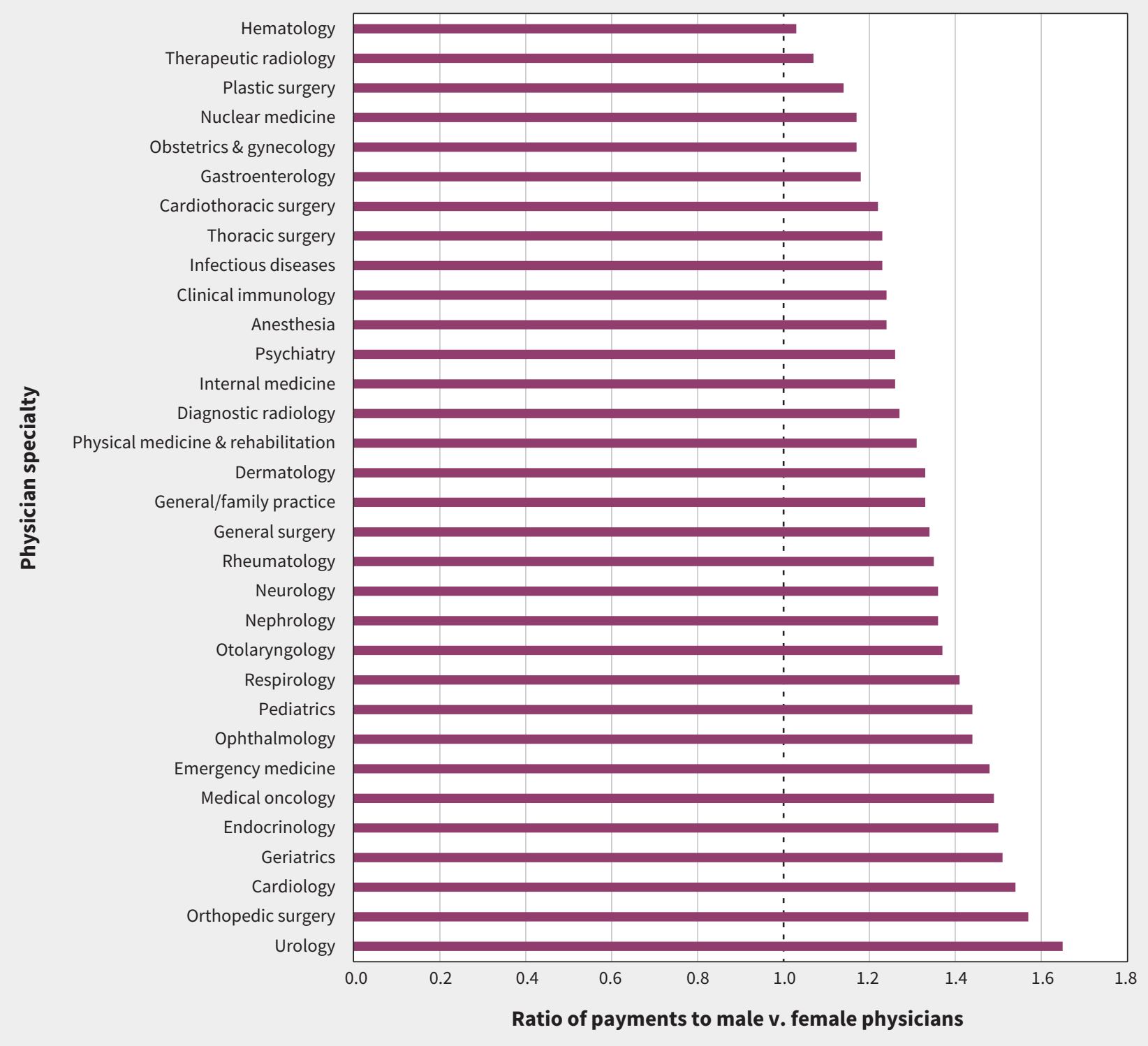

Figure 2: Ratio of average gross fee-for-service payments to male versus female physicians in Ontario in 2016 by specialty. Only physicians billing more than $\$ 100000$ in payments are included in the analysis. A ratio of 1.0 denotes equality in gross fee-for-service payments between male and female physicians; a ratio greater than 1.0 denotes higher payments to males versus females. Data and analysis provided by Dr. Boris Kralj, Faculty of Social Sciences, McMaster University, based on Ontario Health Insurance Plan fee-for-service payments in 2016. 
Association data from 2010 to 2014 showed minimal gender difference in the retirement age of primary care physicians. ${ }^{39}$

Disparities in income likely relate more to the type of work women do compared to men than to work volume or efficiency. For example, Dossa and colleagues ${ }^{33}$ found that, between 2014 and 2016 in Ontario, female surgeons earned 24\% less per hour spent operating than male surgeons. Across the 200 most common surgical procedures, there was no appreciable gender difference in time spent performing the procedure. Rather, women generally performed less lucrative procedures. The findings strongly suggest that, even when women work equal hours, they do not receive equal pay.

\section{What are some of the root causes of the gender pay gap?}

Women in medicine face discrimination throughout their careers. This discrimination is rooted in the history of women's exclusion from the profession, along with the institutional legacies of sexism in medical schools, clinical care arrangements, health care organizations and the fee system itself. In the early stage of their careers, the "hidden curriculum" both subtly and overtly encourages women trainees to enter specific, often lower-paid, specialties. ${ }^{40-43}$ Once female physicians have graduated, they face subtle and often unconscious biases in recruitment and hiring. ${ }^{44}$ There are fewer women in medical leadership roles ${ }^{45,46}$ and of higher academic rank. ${ }^{47,48}$ Men in leadership benefit from the higher income associated with leadership and can also perpetuate the policies and informal support networks that recruit, retain and promote other men at disproportionately higher rates..$^{49,50}$ Women in medicine are more likely to experience imposter syndrome and to have lower salary expectations than men, ${ }^{51}$ but this may result from the anchoring of expectations and feelings of self-worth that go along with lower starting salaries. ${ }^{52}$ Likewise, women see themselves as less capable of negotiating higher pay than $\operatorname{men}^{51}$ but are also more likely to experience consequences from trying to do so..$^{53}$

Biases in clinical care arrangements also lead to pay inequity. A recent report from the UK showed that female general practitioners earn 35\% less than male general practitioners. ${ }^{54}$ Age and hours worked were minor contributing factors. Rather, fewer women were in higher-paying partnership positions. Dossa and colleagues ${ }^{33}$ found a gender distribution in surgical cases to be the major driver of pay inequity between male and female surgeons. Female surgeons disproportionately operate in women, ${ }^{55}$ and these procedures are often remunerated at a lower level. For example, in Ontario, surgeons are paid $\$ 50.90$ for incision under general anesthetic of a vulvar abscess, compared to $\$ 99$ for a scrotal abscess. Similarly, payment for a biopsy is $\$ 39.60$ for the penis and $\$ 26.85$ for the vulva. ${ }^{56}$ That procedures performed mainly in female patients are lower paying is itself suggestive of systemic bias. ${ }^{57-60}$

Referral bias from primary care physicians also contributes to the gender pay gap in surgery. A 2017 study using US Medicare data showed that female surgeons received fewer referrals overall and that, if a patient had a poor outcome after surgery performed by a woman, his or her primary care physician was less likely to refer to any women in that specialty ${ }^{61}$ However, if a poor outcome occurred at the hands of a male surgeon, an equivalent drop in referrals to men was not seen.
The type of work more likely to be performed by women in medicine is relatively undervalued, which contributes to gender pay disparities. ${ }^{62}$ In outpatient settings, women generally spend more time per patient and deal with more issues per visit than men, which leads to lower billing in a fee-for-service model. ${ }^{63,64}$ Moreover, patients expect women physicians to provide more emotional support. ${ }^{65,66}$ In primary care, women are more likely to address psychosocial issues and provide counselling, whereas men are more likely to deliver procedural services. ${ }^{67}$ Procedures generate more revenue per hour than nonprocedural, or "cognitive," services.$^{68}$ Indeed, most male-dominated, top-grossing specialties involve procedures, whereas female-dominated, lower-paid specialties are largely nonprocedural. Notably, men are overrepresented in medical professional associations and negotiation committees, which likely perpetuates these biases. ${ }^{56}$

Finally, the pay gap in medicine is influenced by broader societal attitudes toward women's domestic roles. For example, survey data show that female physicians with young children spend more time doing domestic work than their male counterparts, even in dualphysician households. ${ }^{37,69-71}$ Independent of having children, simply living in a domestic partnership has been shown to have a gender effect on physician work hours, increasing the odds that a woman will work part-time but decreasing the odds of part-time work for men. ${ }^{72}$ Because of the disparities in domestic responsibilities, women with children face more obstacles to academic progression and slower self-perceived career advancement. ${ }^{73}$ These factors influence the proportion of women in leadership roles, which, in turn, affects not just income but also hiring and promotion.

\section{What can we learn from other jurisdictions?}

Most research on the gender pay gap in medicine comes from the US, where there is consistent inequity across a variety of remuneration models. In 2018, the American Medical Association adopted a multipronged policy to address the pay gap, including measures to identify disparities, push for pay structures based on gender-neutral criteria, advocate for training on implicit bias and implement routine gender-based pay audits. ${ }^{74}$ Research on interventions to address hiring and promotion inequities can provide useful outcome measures to guide policy development. ${ }^{75,76}$ For example, when policies addressing gender bias were implemented at the Stanford University School of Medicine, increases were seen in the representation, rank and job satisfaction of women in its faculty. ${ }^{77}$

Internationally, research shows a persistent gender pay gap, including in medical systems organized differently from the Canadian single-payer, mainly fee-for-service model. In the UK, physicians are salaried employees of the National Health Service, which should eliminate many of the time-related issues present in the Canadian billing model. Yet, since 2008, female physicians have consistently earned one-third less than their male colleagues. ${ }^{78}$ In 2017, legislation made it mandatory for the National Health Service to publish data on the gender pay gap, and the British Medical Association has committed to eliminating the pay gap. In 2018, the UK government commissioned a review of the gender pay gap in medicine that is expected to advise on strategies to resolve the gap. ${ }^{79}$ 


\section{What can be done to close the gender pay gap in Canadian medicine?}

Addressing the gender pay gap requires a multipronged approach (Box 1). Medical associations must commit to closing the pay gap. A recent report from the Canadian Medical Association acknowledging the need to correct the gender pay gap is an important step. ${ }^{80}$ However, progress will require accurate, transparent reporting on physician payment by specialty in Canada, stratified by gender, to better understand the current state and report on changes over time. Collection and reporting of data should move beyond a binary view of gender and also include information on race, country of origin and disability in order to understand how multiple forms of discrimination intersect and contribute to pay inequity.

Addressing relativity within the medical profession has historically been fraught, but is an important path to closing the gender pay gap. The value of nonprocedural work, including counselling and psychosocial support, should be reflected in fee codes. Time modifiers or complexity add-on codes would more fairly compensate physicians who see patients with challenging conditions and spend more time per visit. There should not be a fee disparity between surgical procedures performed predominantly in women and equivalent procedures performed predominantly in men. Alternative payment models such as capitation and salary may avoid some of the inequities inherent in fee-for-service remuneration but would require careful implementation to prevent related pay inequities, as seen in the US and UK.
Finally, medical associations and governments need to include more women on negotiating teams with a lens attuned to gender equity.

Leaders in medical school and clinical care need to expose and challenge gender bias in these settings. Medical schools should address the negative hidden curriculum, starting with faculty education. ${ }^{81-83}$ Female trainees should not be directed to enter "family-friendly" specialties, nor should they be warned away from male-dominated specialties or specialties with long hours or demanding physical work. More fundamentally, medical educators should apply a feminist critique to medical education and examine what is taught and whose voices are amplified..$^{84}$

Clinical leaders should be encouraged to take antioppression training and address the institutional systems that perpetuate bias ${ }^{85}$ Hiring processes should be transparent and formalized. Female candidates should be encouraged to apply for positions, ${ }^{86}$ and hiring committees should be diverse, with roughly equal numbers of women and men. Starting salaries should be standard and transparent, obviating the need for negotiation. Organizations should track and report on the gender pay gap within their institution and within leadership. Similarly, practice groups should share earnings internally with a view to gender pay equity. Men in leadership roles should not just mentor women but should also actively sponsor their careers ${ }^{87}$ Physician groups should consider centralized, objective and transparent referral and triage systems to reduce the effects of referral bias.

Medical associations, government and health care organizations should develop programs and policies supporting everyone to take

Box 1: Actions various stakeholders can take to close the gender pay gap in Canadian medicine

\begin{tabular}{|c|c|c|c|c|c|}
\hline \multirow[b]{2}{*}{ Action } & \multicolumn{5}{|c|}{ Stakeholder } \\
\hline & $\begin{array}{l}\text { Provincial/territorial } \\
\text { governments }\end{array}$ & $\begin{array}{l}\text { Professional } \\
\text { associations }\end{array}$ & Faculties of medicine & Clinical leaders & $\begin{array}{l}\text { Individual } \\
\text { physicians }\end{array}$ \\
\hline $\begin{array}{l}\text { Provide transparent } \\
\text { aggregate data } \\
\text { stratified by gender and } \\
\text { other demographic } \\
\text { characteristics }\end{array}$ & \multicolumn{2}{|c|}{$\begin{array}{c}\text { Transparent reporting of physician } \\
\text { payments }\end{array}$} & $\begin{array}{l}\text { Transparent reporting } \\
\text { of salary support and } \\
\text { promotion of } \\
\text { physicians within an } \\
\text { institution }\end{array}$ & $\begin{array}{l}\text { Transparent } \\
\text { reporting of } \\
\text { physician income } \\
\text { within a practice } \\
\text { plan }\end{array}$ & $\begin{array}{l}\text { Ask for data } \\
\text { stratified by gender } \\
\text { and demographic } \\
\text { characteristics }\end{array}$ \\
\hline $\begin{array}{l}\text { Provide antioppression } \\
\text { training }\end{array}$ & \multicolumn{2}{|c|}{$\begin{array}{c}\text { Training for leadership and those on } \\
\text { negotiation committees }\end{array}$} & Training for all faculty & $\begin{array}{l}\text { Training for all } \\
\text { clinical leaders }\end{array}$ & $\begin{array}{l}\text { Act as role models } \\
\text { by doing training }\end{array}$ \\
\hline $\begin{array}{l}\text { Maintain standard, fair } \\
\text { and transparent hiring } \\
\text { and promotion } \\
\text { practices }\end{array}$ & $\begin{array}{l}\text { E.g., for physician } \\
\text { leadership roles }\end{array}$ & $\begin{array}{l}\text { E.g., for committees } \\
\text { and executive }\end{array}$ & \multicolumn{2}{|c|}{ E.g, for new hires, salary support and promotion } & $\begin{array}{l}\text { Advocate for open, } \\
\text { advertised } \\
\text { competitions with } \\
\text { transparent process }\end{array}$ \\
\hline $\begin{array}{l}\text { Actively seek women } \\
\text { for leadership roles }\end{array}$ & $\begin{array}{l}\text { Gender } \\
\text { representation on } \\
\text { negotiation } \\
\text { committees }\end{array}$ & $\begin{array}{l}\text { Gender } \\
\text { representation on } \\
\text { negotiation } \\
\text { committees, } \\
\text { executive and board }\end{array}$ & \multicolumn{2}{|c|}{$\begin{array}{c}\text { - Gender representation on hiring committees } \\
\text { - Actively seek and encourage female } \\
\text { candidates }\end{array}$} & $\begin{array}{l}\text { Actively mentor } \\
\text { and sponsor } \\
\text { women }\end{array}$ \\
\hline $\begin{array}{l}\text { Provide better } \\
\text { maternity and parental } \\
\text { leave programs }\end{array}$ & \multicolumn{2}{|c|}{$\begin{array}{l}\text { Improve maternity and parental benefit } \\
\qquad \text { programs }\end{array}$} & \multicolumn{3}{|c|}{ Support colleagues who are taking maternity and parental leave } \\
\hline Other & \multicolumn{2}{|c|}{$\begin{array}{c}\text { - Address disparities in fee codes for } \\
\text { procedural and nonprocedural services } \\
\text { and for surgical procedures for men } \\
\text { v. women } \\
\text { - Apply gender-based analysis to } \\
\text { discussions of income relativity }\end{array}$} & $\begin{array}{l}\text { - Expose and challenge } \\
\text { the hidden } \\
\text { curriculum, starting } \\
\text { with faculty education } \\
\text { - Apply a feminist } \\
\text { critique to medical } \\
\text { curricula }\end{array}$ & $\begin{array}{l}\text { - Adopt standard } \\
\text { and transparent } \\
\text { starting salaries } \\
\text { - Implement } \\
\text { centralized, } \\
\text { objective and } \\
\text { transparent referral } \\
\text { and triage systems }\end{array}$ & $\begin{array}{l}\text { Support women by } \\
\text { sharing household } \\
\text { labour more } \\
\text { equitably }\end{array}$ \\
\hline
\end{tabular}


parental leaves, regardless of gender, and should adjust advancement criteria to account for such leaves. Partners need to support women in medicine by taking on a larger share of household labour.

Finally, work to address gender pay equity in medicine cannot be done in isolation. The medical profession should remain mindful of the relative privilege of physicians in society and support advances for women struggling in precarious, lower-paid work; solutions for the medical profession should not exacerbate broader societal income inequity. Efforts to close the gender pay gap in medicine should embrace efforts to measure and reduce pay gaps related to other intersecting forms of discrimination, including race and disability.

\section{Conclusion}

Women continue to be paid less than men in medicine. The gender pay gap exists within every specialty and also between specialties, with physicians in male-dominated specialties receiving higher payments. The gap is not explained by women working less but, rather, relates more to systemic bias in medical school, hiring, promotion, clinical care arrangements, mechanisms used to pay physicians and societal structures more broadly. Progress in Canada will require a commitment from medical associations and governments to close the pay gap, starting with transparent reporting of physician payments stratified by gender. We need to go further as a profession to understand how gender, race, disability and other identities intersect to affect gaps in pay and then take action to address these gaps to realize the vision of pay equity for all in medicine.

\section{References}

1. Historic proactive pay equity legislation receives Royal Assent [news release]. Ottawa: Employment and Social Development Canada; 2018 Dec. 13, updated 2018 Dec. 14. Available: www.canada.ca/en/employment-social-development/ news/2018/12/historic-proactive-pay-equity-legislation-receives-royal-assent. html (accessed 2020 Jan. 10)

2. Fine C, Sojo V. Women's value: beyond the business case for diversity and inclusion. Lancet 2019;393:515-6.

3. Kang SK, Kaplan S. Working toward gender diversity and inclusion in medicine: myths and solutions. Lancet 2019;393:579-86.

4. Shannon G, Jansen M, Williams K, et al. Gender equality in science, medicine, and global health: Where are we at and why does it matter? Lancet 2019;393:560-9.

5. Data tables, 2016 census. Ottawa: Statistics Canada; modified 2018 Apr. 26. Available: www12.statcan.gc.ca/census-recensement/2016/dp-pd/dt-td/ index-eng.cfm (accessed 2020 Feb. 21).

6. Ly DP, Seabury SA, Jena AB. Differences in incomes of physicians in the United States by race and sex: observational study. BMJ 2016;353:i2923.

7. Glauser W. Why are women still earning less than men in medicine? CMAJ 2018;190:E664-5.

8. Read S, Butkus R, Weissman A, et al. Compensation disparities by gender in internal medicine. Ann Intern Med 2018;169:658-61.

9. Weaver AC, Wetterneck TB, Whelan CT, et al. A matter of priorities? Exploring the persistent gender pay gap in hospital medicine. J Hosp Med 2015;10:486-90.

10. Roy B. Gender pay gaps in medicine: moving from explanations to action. $J$ Gen Intern Med 2018;33:1413-4.

11. Wiler JL, Rounds K, McGowan B, et al. Continuation of gender disparities in pay among academic emergency medicine physicians. Acad Emerg Med 2019;26:286-92.

12. Spencer ES, Deal AM, Pruthi NR, et al. Gender differences in compensation, job satisfaction and other practice patterns in urology. J Urol 2016;195:450-5.

13. Frintner MP, Sisk B, Byrne BJ, et al. Gender differences in earnings of early- and midcareer pediatricians. Pediatrics 2019;144:e20183955.

14. Butkus R, Serchen J, Moyer DV, et al.; Health and Public Policy Committee of the American College of Physicians. Achieving gender equity in physician compensation and career advancement: a position paper of the American College of Physicians. Ann Intern Med 2018;168:721-3.

15. Mascarenhas A, Moore JE, Tricco AC, et al. Perceptions and experiences of a gender gap at a Canadian research institute and potential strategies to mitigate this gap: a sequential mixed-methods study. CMAJ Open 2017;5:E144-51.
16. Jena AB, Olenski AR, Blumenthal DM. Sex differences in physician salary in US public medical schools. JAMA Intern Med 2016;176:1294-304.

17. Connolly S, Holdcroft A. The pay gap for women in medicine and academic medicine: an analysis of the WAM database [report]. London (UK): British Medical Association; 2009.

18. Lo Sasso AT, Armstrong D, Forte G, et al. Differences in starting pay for male and female physicians persist; explanations for the gender gap remain elusive. Health Aff (Millwood) 2020;39:256-63.

19. Lo Sasso AT, Richards MR, Chou CF, et al. The $\$ 16,819$ pay gap for newly trained physicians: the unexplained trend of men earning more than women. Health Aff (Millwood) 2011;30:193-201.

20. Esteves-Sorenson C, Snyder J. The gender earnings gap for physicians and its increase over time. Econ Lett 2012;116:37-41.

21. Spector ND, Overholser B. Examining gender disparity in medicine and setting a course forward. JAMA Netw Open 2019;2:e196484.

22. Rao AD, Nicholas SE, Kachniarz B, et al. Association of a simulated institutional gender equity initiative with gender-based disparities in medical school faculty salaries and promotions. JAMA Netw Open 2018;1:e186054.

23. Greenberg CC. Association for Academic Surgery presidential address: sticky floors and glass ceilings. J Surg Res 2017;219:ix-xviii.

24. Jagsi R, Griffith KA, Stewart A, et al. Gender differences in the salaries of physician researchers. JAMA 2012;307:2410-7.

25. Apaydin EA, Chen PG, Friedberg MW. Differences in physician income by gender in a multiregion survey. J Gen Intern Med 2018;33:1574-81.

26. Summary report: physicians in Canada, 2018. Ottawa: Canadian Institute for Health Information; 2019. Available: www.cihi.ca/sites/default/files/ document/physicians-in-canada-2018.pdf (accessed 2019 Dec. 12).

27. Csanady A. Ontario's doctor wage gap: just eight per cent of province's topbilling MDs are women. National Post [Toronto] 2016 Apr. 29. Available: https://nationalpost.com/news/politics/ontarios-doctor-wage-gap-just-eight -per-cent-of-provinces-top-paid-mds-are-women (accessed 2019 Dec. 1).

28. Bogler T, Lazare K, Rambihar V. Female family physicians and the first 5 years: in pursuit of gender equity, work-life integration, and wellness. Can Fam Physician 2019;65:585-8.

29. Biringer A, Carroll JC. What does the feminization of family medicine mean? CMAJ 2012;184:1752.

30. Vogel L. Pay gap growing between family doctors, other specialists. CMAJ 2017; 189:E1300.

31. Dhara A. Smile! Women as family doctors. Can Fam Physician 2019;65:497-8.

32. Kralj B. Male FPs out-earn women FPs annually by over $30 \%$ : Ontario data. Medical Post; 2019. Available: https://drbobbell.com/male-fps-out-earn -women-fps-annually-by-over-30-ontario-data/ (accessed 2019 Apr. 26).

33. Dossa F, Simpson AN, Sutradhar R, et al. Sex-based disparities in the hourly earnings of surgeons in the fee-for-service system in Ontario, Canada. JAMA Surg 2019;154:1134-42.

34. CMA Physician Workforce Survey. Ottawa: Canadian Medical Association. Available: https://surveys.cma.ca/en (accessed 2020 Mar. 1).

35. Hedden L, Barer ML, McGrail K, et al. In British Columbia, the supply of primary care physicians grew, but their rate of clinical activity declined. Health Aff (Millwood) 2017;36:1904-11.

36. Gravelle H, Hole AR. The work hours of GPs: survey of English GPs. Br J Gen Pract 2007;57:96-100.

37. Frank E, Zhao Z, Sen S, et al. Gender disparities in work and parental status among early career physicians. JAMA Netw Open 2019;2:e198340.

38. Crossley TF, Hurley J, Jeon SH. Physician labour supply in Canada: a cohort analysis. Health Econ 2009;18:437-56.

39. Petterson SM, Rayburn WF, Liaw WR. When do primary care physicians retire? Implications for workforce projections. Ann Fam Med 2016;14:344-9.

40. O'Connor MI. Medical school experiences shape women students' interest in orthopaedic surgery. Clin Orthop Relat Res 2016;474:1967-72.

41. Hill E, Bowman K, Stalmeijer R, et al. You've got to know the rules to play the game: how medical students negotiate the hidden curriculum of surgical careers. Med Educ 2014;48:884-94.

42. Phillips CB. Student portfolios and the hidden curriculum on gender: mapping exclusion. Med Educ 2009;43:847-53.

43. Kwon E, Adams TL. Choosing a specialty: intersections of gender and race among Asian and white women medical students in Ontario. Can Ethn Stud 2018;50: 49-68.

44. Mascarenhas A, Moore JE, Tricco AC, et al. Perceptions and experiences of a gender gap at a Canadian research institute and potential strategies to mitigate this gap: a sequential mixed-methods study. CMAJ Open 2017;5:E144-51.

45. Carnes M, Morrissey C, Geller SE. Women's health and women's leadership in academic medicine: Hitting the same glass ceiling? J Womens Health (Larchmt) 2008;17:1453-62 
46. Downs JA, Reif ML, Hokororo A, et al. Increasing women in leadership in global health. Acad Med 2014;89:1103-7.

47. Zhuge Y, Kaufman J, Simeone DM, et al. Is there still a glass ceiling for women in academic surgery? Ann Surg 2011;253:637-43.

48. Jena AB, Khullar D, Ho O, et al. Sex differences in academic rank in US medical schools in 2014. JAMA 2015;314:1149-58.

49. Ruzycki SM, Freeman G, Bharwani A, et al. Association of physician characteristics with perceptions and experiences of gender equity in an academic internal medicine department. JAMA Netw Open 2019;2:e1915165.

50. Hoops HE, Brasel KJ, Dewey E, et al. Analysis of gender-based differences in surgery faculty compensation, promotion, and retention: establishing equity. Ann Surg 2018;268:479-87.

51. Gray K, Neville A, Kaji AH, et al. Career goals, salary expectations, and salary negotiation among male and female general surgery residents. JAMA Surg 2019;154:1023-9.

52. Moss-Racusin CA, Dovidio JF, Brescoll VL, et al. Science faculty's subtle gender biases favor male students. Proc Natl Acad Sci U S A 2012;109:16474-9.

53. Bowles HR, Babcock L, Lai L. Social incentives for gender differences in the propensity to initiate negotiations: sometimes it does hurt to ask. Organ Behav Hum Decis Process 2007;103:84-103.

54. Mahase E. Gender pay gap in general practice is 35\%, report finds - owing to age, working hours, and partnerships. BMJ 2020;368:m112.

55. Oberlin DT, Vo AX, Bachrach L, et al. The gender divide: the impact of surgeon gender on surgical practice patterns in urology. J Urol 2016;196:1522-6.

56. Ontario Health Insurance Plan: OHIP schedule of benefits and fees. Toronto: Ministry of Health and Long-Term Care. Available: www.health.gov.on.ca/en/ pro/programs/ohip/sob/ (accessed 2020 Feb. 20).

57. Benoit MF, Ma JF, Upperman BA. Comparison of 2015 Medicare relative value units for gender-specific procedures: gynecologic and gynecologic-oncologic versus urologic CPT coding. Has time healed gender-worth? Gynecol Oncol 2017;144:336-42.

58. Cherouny P, Nadolski C. Underreimbursement of obstetric and gynecologic invasive services by the resource-based relative value scale. Obstet Gynecol 1996;87:328-31.

59. Izenberg D, Oriuwa C, Taylor M. Why is there a gender gap in Canadian medicine? Healthy Debate.ca 2018 Oct. 18. Available: https://healthydebate.ca/2018/10/ topic/gender-wage-gap-medicine (accessed 2019 June 15).

60. Yutzie JD, Shellito JL, Helmer SD, et al. Gender differences in general surgical careers: results of a post-residency survey. Am J Surg 2005;190:955-9.

61. Sarsons $\mathrm{H}$. Interpreting signals in the labor market: evidence from medical referrals [job market paper]. Working paper. 2017. Available: www.fas.nus. edu.sg/ecs/events/seminar/seminar-papers/7\%20Mar\%202019.pdf (accessed 2020 Mar. 1).

62. Clarke JT. Fee-setting, a study of decision-making by the medical profession in Ontario [doctoral dissertation]. Ottawa: National Library of Canada; 2001.

63. Roter DL, Hall JA, Aoki Y. Physician gender effects in medical communication: a meta-analytic review. JAMA 2002;288:756-64.

64. Hedden L, Barer ML, Cardiff K, et al. The implications of the feminization of the primary care physician workforce on service supply: a systematic review. Hum Resour Health 2014;12:32.

65. Linzer M, Harwood E. Gendered expectations: Do they contribute to high burnout among female physicians? J Gen Intern Med 2018;33:963-5.

66. Samra R. Empathy and burnout in medicine - acknowledging risks and opportunities. J Gen Intern Med 2018;33:991-3.

\section{Competing interests: None declared.}

This article has been peer reviewed.

Affiliations: Department of Family Medicine (Cohen), Queen's University, Kingston, Ont.; Division of Family Medicine (Cohen), Trenton Memorial Hospital, Trenton, Ont.; Department of Family and Community Medicine (Kiran), St. Michael's Hospital; Department of Family and Community Medicine (Kiran), University of Toronto; MAP Centre for Urban Health Solutions (Kiran), Li Ka Shing Knowledge Institute of St. Michael's Hospital; Institute of Health Policy, Management and Evaluation (Kiran), University of Toronto, Toronto, Ont.

Contributors: Michelle Cohen conducted the data analysis and drafted the manuscript. Both authors conceived of and designed the work, revised the manuscript critically for important intellectual
67. Cohen M, Ferrier BM, Woodward CA, et al. Gender differences in practice patterns of Ontario family physicians (McMaster medical graduates). J Am Med Womens Assoc (1972) 1991;46:49-54.

68. Sinsky CA, Dugdale DC. Medicare payment for cognitive vs procedural care: minding the gap. JAMA Intern Med 2013;173:1733-7.

69. Ly DP, Jena AB. Sex differences in time spent on household activities and care of children among US physicians, 2003-2016. Mayo Clin Proc 2018;93:1484-7.

70. Buddeberg-Fischer B, Stamm M, Buddeberg C, et al. The impact of gender and parenthood on physicians' careers - professional and personal situation seven years after graduation. BMC Health Serv Res 2010;10:40.

71. Ly DP, Seabury SA, Jena AB. Hours worked among US dual physician couples with children, 2000 to 2015. JAMA Intern Med 2017;177:1524-5.

72. Lachish S, Svirko E, Goldacre MJ, et al. Factors associated with less-than-fulltime working in medical practice: results of surveys of five cohorts of UK doctors, 10 years after graduation. Hum Resour Health 2016;14:62.

73. Carr PL, Ash AS, Friedman RH, et al. Relation of family responsibilities and gender to the productivity and career satisfaction of medical faculty. Ann Intern Med 1998;129:532-8.

74. O'Reilly KB. Physicians adopt plan to combat pay gap in medicine. Chicago: American Medical Association; 2018. Available: www.ama-assn.org/practice -management/physician-diversity/physicians-adopt-plan-combat-pay-gap -medicine (accessed 2020 Mar. 1).

75. Morris $\mathrm{M}$, Chen $\mathrm{H}$, Heslin MJ, et al. A structured compensation plan improves but does not erase the sex pay gap in surgery. Ann Surg 2018;268:442-8.

76. Laver KE, Prichard IJ, Cations M, et al. A systematic review of interventions to support the careers of women in academic medicine and other disciplines. BMJ Open 2018;8:e020380.

77. Valantine HA, Grewal D, Ku MC, et al. The gender gap in academic medicine: comparing results from a multifaceted intervention for Stanford faculty to peer and national cohorts. Acad Med 2014;89:904-11.

78. Rimmer A. The gender pay gap: female doctors still earn a third less than male doctors. BMJ 2017;357:j1967.

79. Rimmer A. Review of $£ 10000$ gender pay gap in medicine is launched. BMJ 2018;361:k2366.

80. Addressing gender equity and diversity in Canada's medical profession: a review. Ottawa: Canadian Medical Association; 2018. Available: https://www. cma.ca/sites/default/files/pdf/Ethics/report-2018-equity-diversity-medicine-e. pdf (accessed 2020 Feb. 20)

81. Gofton W, Regehr G. What we don't know we are teaching: unveiling the hidden curriculum. Clin Orthop Relat Res 2006;449:20-7.

82. Holmes CL, Harris IB, Schwartz AJ, et al. Harnessing the hidden curriculum: a four-step approach to developing and reinforcing reflective competencies in medical clinical clerkship. Adv Health Sci Educ Theory Pract 2015;20:1355-70.

83. Mahood SC. Medical education: beware the hidden curriculum. Can Fam Physician 2011;57:983-5.

84. Sharma M. Applying feminist theory to medical education. Lancet 2019;393:570-8.

85. Pritlove C, Juando-Prats C, Ala-Leppilampi K, et al. The good, the bad, and the ugly of implicit bias. Lancet 2019;393:502-4.

86. Johnson SK, Hekman DR, Chan ET. If there's only one woman in your candidate pool, there's statistically no chance she'll be hired. Boston: Harvard Business Publishing; 2016.

87. Patton EW, Griffith KA, Jones RD, et al. Differences in mentor-mentee sponsorship in male vs female recipients of National Institutes of Health grants. JAMA Intern Med 2017;177:580-2.

content, gave final approval of the version to be published and agreed to be accountable for all aspects of the work.

Funding: Tara Kiran is the Fidani Chair in Improvement and Innovation at the University of Toronto. She is supported as a Clinician Scientist by the Department of Family and Community Medicine at the University of Toronto and at St. Michael's Hospital. She is also supported by Health Quality Ontario and the Canadian Institutes of Health Research as an Embedded Clinician Researcher.

Acknowledgements: The authors thank Dr. Boris Kralj for sharing data from his research. They also thank Dr. Fahima Dossa, Dr. Ritika Goel, Dr. Irfan Dhalla, Dr. Nancy Baxter, Dr. Sharon Straus, Dr. Lesley Barron, Dr. Reena Pattani and Dr. Malika Sharma for reviewing the manuscript and providing feedback.

Correspondence to: Michelle Cohen, michelle.cohen@queensu.ca 